\title{
Siavash Status in Mythology and Rituals
}

\author{
Seyed Salam Fathi \\ Master in ancient history of Iran, Department of History \\ Islamic Azad University of Tehran \\ Central Branch, Iran \\ Salam_fathi53@yahoo.com
}

\begin{abstract}
Siavash character as one of the central figures of Iran's national epic is seen in myth, the Avesta, Pahlavi texts, and archaeological findings. Siavash etymology and discussing his status in Iranian myths and comparing it with legends of different nations in five areas of "rituals," "the first man," "the issue of martyrdom," "plants of Siavash blood," and "mourning for Siavash" are among the issues that have been considered in this study.

Attention to Siavash's position in Iranian rituals and continuation of his social functions in the form of traditions such as "Haji Firouz," "Nowruz," and "Ceremony of cock killing" are of the constituents and characteristics that are studied in close contact with each other.

Siavash presence in the text such as Avesta, Bundahisn and Numinous wisdom is the very presence in myth and Shahnameh of Ferdowsi, so the most important actions he has have also been studied in these texts. Central structure and thought-centeredness in each of the chapters mentioned are based on the idea of "Mehrdad Bahar" based on Siavash's being "Herbal God," so it is obvious that the concept of martyrdom, plant of Siavash blood, and mourning are all affected by this opinion.
\end{abstract}

Keywords: Siavash, myth, plant, mourning, Shahnameh

\section{INTRODUCTION}

Siavash is one of the most pivotal characters of Shahnameh, who was born from an Iranian father and Turanian mother. He is the son of one of the most prominent Kiani kings (Kavoos), who provides the death of his own in the land of Turan with his irrational deeds.

The word Siavash in Avesta is given in form of the compound word "syavarshan" that consists of two parts (syava) and (arshan); altogether it can be interpreted as "black stallions holder" (Bartholome, 1961: 163).

Mehrdad Bahar has considered another meaning of the word, which is "black man," because in his idea Siavash ritual is connected with Vegetation-god praising rituals and aborigine god and connects to Babylonian Tammuz and Ishtar rituals, and older than that to Sumerian rituals. Hence, the Avestan word means black man or dark faced, referring to the black color tainted on face in this ceremony or a black mask used (Bahar, 1999: 194-195). According to this concept, Siavash is closely and logically connected to "Haji Firouz" that is somehow archetype of his personality.

In Avesta, "Farvardīn Yašt" and "Zamyad Yašt" Siavash's name has come as "Kay syavarshan" among the names of eight Kiani kings (Kayghobad, Kayepiveh, Kayarshan, Kaybiarshan, Kaypashin, Keykavous, Kaysiavash, and Kay Khosrow). The names of the eight Kayan in Avesta belongs to period pefore Zoroaster and Vishtasb, and all are considered as a family, so Siavash should be considered after Kavus and before his son Kay Khosrow the mighty king of one of the eastern regions, such as Balkh that is killed in battle with Touranian as the invading Arian tribes beyond the Oxus.

The word "kawi" that is as "kay" in Avesta form used to come before the kings' names was only specific to areas of the East. According to them, Kiynian reign is a historical charts from the establishment of immigrant Arians in eastern Iran until the advent of Zoroaster (Christensen, 2002: 11 and 47), thus according to the Avesta text, Siavash must also be considered as a king. However, 


\section{Seyed Salam Fathi}

according to Ferdowsi report given of his story of life, he has never been king of Iranshahr, but in terms of purity, it can be assumed that, in the days before Zarathustra, or near Zoroaster period, he has been known as the king of Iran (Safa, 2008: 493-494).

Siavash character in Shahnameh is mixed with stories of love and jealousy, innocence and homeless. In fact, he is one of the most talented myth-epic figures of Iran that has gone through the process of gradual transition from the divine to the human level. In this study, the evolution of Siavash, which has created a perfect man of him in Iranian national epic, in rituals and myths, Avesta, Pahlavi texts evaluated in archaeological findings. It is understood that the presence of this Ahura prince within the myth encompasses several components, each of which will be examined in turn.

\section{SiAVASH IN MYTHOLOGY}

Myth is a coherent tissue from traditional narratives and sacred beliefs considered in human primary societies. Every nation's myths have traditions about the creation of the universe, the gods, and humans. If we consider myth as an unattainable ideal fact that human mind has always been in search of it, Siavash story can be called a myths. This myth with its worthy of attention aspects have always been the symbol associated with all the facts surrounding his mysterious personality. With a little investigation in the myths of different nations, it can be concluded that many of the characters that have a special place in the national epic, in the distant past were myths that in time later by the people and needs of historical societies have gotten myth color and even have their own reality. Many of these epic heroes, in time were gods of vast areas of the heavens that had limited scope of this universe, but in the development and passage of time, they have gotten an earthy figure. According to these definitions, Siavash can also be seen among those gods who are drawn to earth to carry out their duty. Siavash story is a myth of the indigenous people of this land that after the arrival of Arian immigrants and over time has lost its sanctity and old nature, but due to its association with the practical life of the community is still in the context of the community the living. The basic motif of this story is death and re-life of nature in the form of God on Earth and his martyrdom and regeneration. Thus, the most important mythological analysis of Siavash that exist is Bahar's idea that knows him as "martyred vegetation-god," so that family farmers in ancient times, by seeing germination of plants and growth at a specific time and drying at a later stage concluded that the plant cannot become green again in spring before death. The belief that is the base of their farming life and their life basic principle affect their worldview and ideology, so that for plants and vegetable life of gods that generalize them to extend it gradually towards their dead. The fundamental unity of life and death in the idea of human prehistory has found mythologized state suggesting the creation of a kind of archetype of "vegetation-gods" in different civilizations throughout history. According to this view, which was once a firmly held belief, fertilizer God dies and disappears under the earth, but after this necessarily mythical developments, it goes back to nature in the springtime.

This ritual in different species can be seen from the Indus Valley to Greece and Egypt. Ramayn story in India, Siavash Iran, Tammuz or Dumuzi in Mesopotamia, Baal in Syria and even the story of Joseph in the Old Testament, all represent death and life again (Bahar, 1999: 398-399).

The actions of each of these characters are somehow associated with life and death issue of vegetation-god that is death, martyrdom, fire dive, being exiled, or falling into dark prison are all substitute and symbols of this issue that the seeds for further growth, must remain hidden underground for some time and after this period that the seeds is influenced by chemical agents reaches the necessary level of growth and development and gets away from death world.

About the characters mentioned, it is the same that is getting out of the fire, release from exile and prison, ruling and having power all are the symbol of life again after a period of annihilation.

Amid these samples, the focus is on Siavash, so according to Bahar, if we do not consider Siavash story from Iran and seek its origins in Mesopotamia, we should match all its elements and members that have changed over time with this Mesopotamian myth story of Dumuzi. In addition, to do this, we first need to dwell a bit on Dumuzi story.

Can, unmistakably, from these stories - from Avesta to Bukhara history - say that Siavash is vegetation-god like the gods of Mesopotamia and Egypt and Asia Minor like Tammuz and Adonis?

It is said that, it can be accepted that couples like Siavash and Soudabeh, Isis and Osiris, Tammuz and Ishtar, Adonis and Aphrodite, Otis and Sibel, even Joseph and Zulaykha, in India Ramma and Cita are 
all linked to agriculture and fertility. Their death is sinking of seeds in the ground and returns from the dead, re-grow, and renewal of plant life, going into exile, has the same meaning.

Dumuzi - bless giving and fertilizer god of Sumerian - spouse of Innin - feminine fertility and goddess of city of Uruk has enjoyed power and many facilities. Innin, cast Dumuzi into the hands of demons to take him to the world of the dead with the quilt of not showing the deep respect towards her. Dumuzi is taken to the Underworld and finally, during mythological developments comes on the ground and re-marries goddess of love and fertility.

Siavash as Dumuzi is the god of plantation: he goes into the fire, it can be seen as drying and yellowing of plants, but he is happy and victorious out of the fire that is a symbol for the arrival of spring and the plants becoming green.

In other words, this myth represents the death and resurrection and the pattern of fall and spring. Siavash's drooping and regrowth of Kay Khosrow is the most basic symbol of death and resurrection and the pattern of fall and spring. Siavash's drooping and regrowth of Kay Khosrow is the most basic symbol of god-like death of this martyr and greening of blood of siavashan.

In this case, the water goddess in Sumerian mythology was "Innin" has been replaced by Soudabeh. Soudabeh means "owner of beneficial water." In this sense, she, like Innin, causes the death of plantation and fertility god, in the story Siavash is her stepson (Ibid: 195).

Soudabeh sends Siavash to the world of dead, but he returned in form of Kay Khosrow to being and killed Afrasiab, who was somehow the symbol of drought. Siavash's presence in the field of mythology can be examined in several features including customs, the first man issue, martyrdom, and mourning and so on. Each of these components to define a special place in the mythology describes him.

\section{SHAHNAMEH SiaVASh DifFERENCE WITH VegETaTION-GODS}

If get the story of Siavash out the hands of Mesopotamian mythology in Shahnameh and see it in the screen of East myth with its true identity, the true similarity between Rama and Siavash shines out. Mesopotamia and Asia Minor gods are very tragic.

"In this ritual, there is no sign of gods' of kindness and noble sentiments. They are full of bloodshed and mutilation of living beings. It is not known that theses rituals where the children are murdered and living things are sliced are geld with what intentions and purpose in the world."

1. The first description of Siavash in the return of Zabulistan is the indisputable distinction of Kiani Prince with strange creatures. Cavus Shah of Iran is surprised with the fit of son:

He was so surprised and thus praised him like the great people

There were so many people looking in wonder to his great greatness and magnanimity

With such a young age he was as if of great sagacity (Second book, P: 209)

2. Siavash beauty: the beauty of Siavash in Shahnameh and Pahlavi literature that is mistakenly assumed as the charms of vegetation-gods in thinking has a quite different meaning. In the previous pages, it is talked of Adonis seduction and lovers' falling into the trap of his beauty.

Otis God of plantation is listed in counterparts of Siavash and Soudabeh and with the same beauty seduces the mother in his love, but the beauty Siavash has a different origin. In response to Soudabeh who is seduced by him, he calmly says:

And you asked of my beauty of my face and you mixed with my love

God created me of his beauty

and nurtured and supported me (Second book, P: 223)

Siavash beauty is divine rare in the former kings. God beauty is not the same as Kiani beauty. Kiani beauty indicates eligibility of king.

3. Siavash's plant growing does not mean fertility nor the promise of blessings and abundance of grain. It does not mean of return of Siavash either, because in this happy story we are aware of Khavarish in paradise. Kiomarth, the first man, in the Zoroastrian tradition is more plant than Siavash. 


\section{Seyed Salam Fathi}

Of his sperm plant grows. "Kiomarth lived for thirty years friendly and when he died conception came out of his lion and went down into the earth for forty years stayed in the womb of the earth. From this sperm two rhubarb-like plants grew, and then he evolved hominid genus plant: one male and the other female." (Christensen, 1984: p. 93)

4. Siavash Kiani Prince: Arthur Kristen in Kianids, after the likening of Kuyan in Gahan and Yasht and assuming Vishtasb supporting Zoroaster in Shahnameh as the same, raises the question whether Kiani Shah of Shahnameh are a historic or mythological dynasty? The Kiani's lineage itself is known as history:

"We should accept a period of reign of Cui Heo Serveh (Kay Khosrow) and Cui Vishtasb (Goshtasb), and it is not too far from the truth if we assume that Kawi dynasty's reign "Kianian" is historical charts of the time after the immigration of Arian in east Iran and establishment as a Royal neatly method that has lasted until Zarathustra period.

According to this introduction, it should be said that in lands located in central deserts of Iran and the basin of the Indus, the Aryan tribes that came from the north formed tyranny below the reign of kings that had the title Kay. One of the Kays - Avasdan (Cavous) - brought all lands under his obedience (Christensen, 1957: pp. 50-48)."

Many Iranologists did not agree with this theory of Christensen. One of them was Georges Dumézil, designer of Indo-European three-duty idea in the book mythology and epic, and Stig Vikander the leading researcher of the University of Uppsala, acknowledged Kiani kings' epic as mythology.

\section{SiavaSh in Rituals}

Development of myth depends on the use of rituals in societies with myth; in fact, myths develop by rituals and survive. To the extent that people strive to maintain their national traditions, myths will continue among them.

After passing the mythological era, Siavash myth continued among us by rituals that ware still alive. Of the rituals that continue today are Haji Firouz, New Year, and killing cocks after the death of loved ones.

\section{SIAVASH AND ITS RELATIONSHIP WITH HAJI FIROUZ}

As previously mentioned Siavash as "martyred vegetation-god" once goes to the realm of darkness and dead to the world and then returns to the world of life as Kay Khosrow.

This ceremony is especial to the feast of Nowruz and spring when plants re-grow and the nature greens. It is at this time that "Haji Firouz" with a dark face, red robes, and tambourines in hand appears.

It seems to Bahar that his face black color is due to returning from the dead to bring rain and blessing and his red robes are probably the symbol of life and blood again, this black and red together represent life and death that are joined together.

Haji Firouz tambourine and his singing that in the story of Dumuzi is seen in form of flageolet is an indicator of rain bringer magical dances performed to bring rain (Bahar, 19998: 264-265)

Siavash martyrs and plant grows of his blood, and Kaykhorso is in fact, a symbol of his return to this world. This seems logical when you consider the meaning of Siavash as "black man" according to Bahar (Bahar, 1994: 211-215).

\section{SiavaSH AND NOWRUZ}

Celebration of the renewal of the nature has long had a close relationship with Siavash as "vegetationgod" in Iran. Nowruz is the revival of nature and resuming growth and lush, so it has a special status and leads them to worship the divine that is somehow associated with plant growth. So we can say that this Nowruz, it the Nowruz of farmers and those who believe in God.

Siavash, who after death is seen in robe of plant, has been a strip of prosperity and blessing for the people that is one of the important parts of farming life. It is on these days that nature and people enjoy their time and backing again. 


\section{Siavash AND Ritual OF Killing CoCKS}

According to Narshakhi tradition, Bukhara Magi considered Siavash's grave to be in Bukhara eastern gate (gate of straw sellers) were aware of " Bukhara Magi endear that place and after sunrise of Nowrouz very year they take a cock and kill it there (Narshakhi, 1992: 32-33)."

Cock is of the mythological birds in Iran's culture, because it is the first being that with Ahura voice tells of the coming sun. This bird is particularly important in Zoroastrian religion but killing it in mourning Siavash is like a norm (Mazdapour, 1990: 144)."

Today's image of killing a cock among some ethnic groups is due to the good omen from of this bird that is some kind of victimization of the sins of the dead person; this victimization is not unrelated to victimization of Siavash by evil and impurity to purify the world.

\section{Siavash as the First Man}

Connection between people and plants is an ancient mythological history. This background that in the story of Siavash is seen as plant of Siavashan blood growing from his blood has led some scholars of mythology and culture to consider Siavash among the "first man." 1

According to Sarkarti, in Siavash time, Afrasiab is the sample of evil and Zahhak in the mythical time, because as evil and Zahhakkill the man first, Allah created cow and Jamshid and Barmayoun, Afrasiab also kills Siavash and Aghrirath. From these two Siavash is example of the first man and like Kiomarth after his death a plant grows of his spilled blood.

Aghrirath is modified species of cattle "Og dad" that according to religious traditions is called Gopet King that from leg to half body is cow and from the middle of body up, it is human (Srkarti, 1978: 116-117).

According to Khaleghi Motlagh, Siavash like Kiomarth can be one of the examples of first man in myths and epics of Iranians. He explained the three reasons and three features in common between Siavash and Kiomarth to prove his claim:

First, Siavash and Kiomarth both go to a formidable and deep sleep before death:

"In case of Kiomarth in Bundahisn (Part IV), it is stated that when death reached him God put him to sleep as a stanza and when he opened his eyes, he saw the physical world as dark as the night and the earth was nearly empty except for a shred of wrongdoer animals." (Khaleghi Motlagh, 1983: 227)

In Ferdowsi's narrative, before Afrasiab' attack, Siavash goes into a deep sleep into a deep and sees the events that will occur in the future for him:

For the fourth night that beauty

He shook and got out of sleep

Afrasiab's daughter asked rapidly

Siavash told her that

I had such a dream, my grace

And there was a fire mountain on the other side

I entered that great burning fire

In one hand, you had water in the other fire

When you saw me towards the angry fire, was sleeping nicely and calmly

and roared like a drunk beast

that what dream you had, the smart king

do not tell anyone of my dream

that there was an enormous river

and by the river there were so many weapons

and Siavash was burning in it

you were by the beast and Afrasiab

you made that fire bigger

(Ferdowsi, 1999, 3/443)

The second common feature of Siavash and Kiomarth is submission and non-resistance to enemy attack. Kiomarth is defenseless against the onslaught of evil and surrenders, and Siavash shows no a reaction against cunning of Garsivaz and decision evil of Afrasiab and even asks the Iranians to stop resistence.

\footnotetext{
${ }^{1}$ Bahman Sarkarti in an article titled "Iranian national epic mythological foundation" and Jalal Khaleghi in an article titled "Shahnameh and the issue of first man" have dealt with this issue.
} 


\section{Seyed Salam Fathi}

The third similarity is redemption of the dust that they died in: "As with the death of Kiomarth a drop of semen from his back drips into the soil and plant life grows, after Siavash death the in the place his blood dropped the same happened, which has therapeutic trait (Khaleghi Motlagh, 1983: 227).

Therefore, it is observed that Siavash and Kiomarth have several common and important features showing that Siavash was also among the first humans in the Persian tradition, but with the evolution of the epic to myth, many of its lines have been wiped out.

\section{Siavash as THE EPITOME OF MARTYRDOM}

In any culture, blood of martyrs feeds and fertilizes the religion tree that is why the issue of martyrdom in relation to the personality of Siavash has a pivotal role both in mythological and epic dimensions, since it is with his death that the myth of martyrdom takes form at the heart of Iranian culture and continues long after.

Siavash is the evolved sample of the human that has grown and reached maturity in all aspects, so it is natural that he is seen as the origin of primers and sacred social values. He always represent people that in the cause of advancing the interests of the community are the victim of bad thinking, ignorance and suspicion of others that is why in the passing of myth to epic history, many people have become his successor.

In mythology, Siavash is the god of plants, he ought to die so lush and refreshing to be returned to nature; this belief has found its way in some kind to national epic and it is when after his martyrdom, of his blood, "Siavashan blood" plant grows. This plant is reinforcing beliefs that know him as vegetation-gods.

Siavash martyrdom is not limited only to mythological aspect. He and Islam as strong beliefs of Iran's culture that changed the Iranian culture movements are transferred from Iranian culture to IranianIslamic culture. A man who lived in this cultural change was trying to, while retaining the traditional beliefs and ideals, set foot in the new stage of civilization and religious beliefs and set the clothes of his great artistic community to a religious figure.

Siavash mythological transformation in history appears as Imam Hussein (pbuh). In fact, mythical Siavash gives his place to historical Imam Hussain (pbuh). The people of Iran with great support from the martyrdom of Siavash remember Imam Hussein (pbuh) to celebrate:

"Martyrdom is a negative epic, either in Hussein or Siavash, desire or potential of disciples who are not born and do not find corporeality and transfer to a perfect intention of the heavenly man. In a world where man becomes negligible in any case, death is the fate of respected, in particular if he is an embodied devotee that will be locked and as his death is undue and has a more tragic deaths, respond to the needs of the spirit of the followers is more! From this perspective, martyrdom is the perfection and necessary conclusion is such a hero." (Maskoub, 1989: 93)

Thus, we can assume Siavash martyrdom in Iranian society, which is somehow the old model of historical martyrdoms after himself, as a kind of transcendence, for the death of such people is far more valuable than their lives.

Siavash death is a sacred martyrdom to unite him with the truth and unity, because although he does not choose death but embrace it. Being aware of the secrets hidden by his charisma, he knows if he does not comply with death, the duty of Kay Khosrow in this world is not reached, so without the slightest protest accepts the deaths and completes his start.

Siavash is created of goodness, to stabilize kindness, he lives a tough life, in the end even dies harder, so that all the good and goodness in the world come to eternal unity:

"The soul of the creator manifests in an incarnation of the chosen and ironically they become a martyr." (Ibid. 95)

In the world of myth, fertility and plant are closely related to human and human life, in such a way that has led to a close relation and interaction between humans and plant.

Khune Siavashan or Parsiavashan plant, which has benefited from this mythical interaction in connection with Siavash, is a mysterious plant that grows after the killing of Siavash from his blood. This plant certainly has a mythical function, because it has found a special status in mythological narratives of Iran, as can be seen in the lives of Zarathustra Kiomarth, Key Khosrow, and Mithraism. 
In pre-Islamic literature, Kiomarth is the first sample of man and even the first king who put the tradition of throne and reigned for thirty years. When the demon attacked and ended his life, of soil on which his semen dropped a plant called "rhubarb" grew that has a long stem fifteen and leaves. Later this plant changes from plant form and turned into human form and created "mashya and mashyana" as the parents of all people (Christiansen, 2004: 13-17)

In Avesta tradition, after sky, water, land, and before sheep and cattle, Hormizd created the plant. This indicates the importance of plant and growth in the course of creation of the world and mankind (Bahar, 1999: 44-47).

In Zoroaster's life, a plant called Haoma plays a fundamental role that in the birth and creation that had the mission like that of Siavash and Kay Khosrow was very important. ${ }^{2}$

In Mithraism, this plant has a mythical presence, because when Mitra sacrifices the bull, from its blood a plant grows that brings fertility and greenness to land (Sarkhosh Curtis, 1994: 13).

In the Siavash myth, his turning into plants and plant transformation to Kay Khosrow is a remarkable point that defines his essence god nature and bless and generosity. Siavash as an example of vegetation-god in ancient Iranian mythology as a seed that has all human values in his heart goes underground and after a due process emerges as Kay Khosrow utopian and epic myth king. He, who has emerged from a plant transformation, brings refreshing green space to mythical - epical space of Iran.

Although this plant mysterious and ambiguous and functional properties, it has always been focused on because it creates human beings that myth and history have seen only once.

When Alexander goes to the tomb of Siavash in "Siavashgerd" finds his soil red, there is fresh blood flowing in the soil where a green plant has grown. (Callisthenes false, 1964: 243) anonymous author of "Majm Altavarikh" also referred to the issue:

"Siavash was killed in Turkestan in the dumb heaven he had made and a plant grew of his blood called "Khune Siavashan" (Bahar, 1939: 262).

An eternal plant grows out of Siavash blood; in fact, some Siavashes grow to cleanse the world of impurity and inaccuracies. Perhaps that is why Ferdowsi does not announce the death of Kay Khosrow in Shahnameh said Kay death not because his disappearance is an emblem and symbol of the continuation of anti- oppression of clean and unique human.

"This plant is the mysterious seedlings of garden of Life. A promising sign of human spirit need that in eternal conflict wisdom is desirous for that, so that at least half exhausted sprit of justice, truth, and freedom remains in the world. In this way, even if thousands of thousands of victims are given, as in the war between Iran and Turan, there is no fear, because one should resist the greatest danger that has threatened humankind since creation, and it is the extinction of humanity." (Eslami Nadoushan, 1989: 223-224)

\section{MOURNING FOR SIAVASH}

According to Bahar, that was earlier discussed, Siavash character in narratives about him a long time ago (at least the third millennium BC) was owned by Dumuzi. The feast of the beginning of the year in Mesopotamia was in fact the return of martyring god. Thus, he as punishment of goddess of water Innin- travels to the underground world. In nature, at this stage, the plants should be underground and experience the death someway. After this fall, people on the death of Dumuzi come out in groups of mourners to weep on.

Crying for people of Mesopotamia has been a symbol of rain. This means that they were crying and overdo it so that the God of heavens tendered and forced to cry. Indeed, at the time of death of vegetation-god and grain cultivation practices, people playing the magic trick of crying, because they made the gods by magic and trick. People magical cry effect made the gods to send a beneficial and fertile tear that is rain.

\footnotetext{
${ }^{2}$ See Aziz Rezai, ancestry ancient Iranian religion, wave Publication, Tehran ,1374: 102.
} 


\section{Seyed Salam Fathi}

When this action with the success of mourners happened, rain and blessings came from the heavens to the earth. At this time, Dumuzi returned to the world and life and remarried water goddess. In nature, the plant emerges from the soil and start to grow. In the nature god used to martyr, and his living again was associated with the gala. Since god getting life again and fertility of land was happening symbolically and successively, people celebrated the New Year. This belief was common in the Western Asian culture, so it can be generalized to Siavash story.

Studying mourning for Siavash in the field of mythology is mourning for the martyring god that after his deaths arose and brought fertility and blessing to the people.

Mourning for Siavash in Iran had an important ritual role. This ritual is closely connected to the days before the New Year in this country. A few days before the beginning of the year people went to the tombs, took lights, and began to weep to revive the spirits of nature to help them.

This ancient ritual still runs among the Iranians. Taking lights and candles to the graves and lighting them at the tomb goes back to the mythological belief that spirits of the dead return to their home and thus their return path will be cleared. This suggests that the spirits in addition to the possibility of returning have the ability to manipulate the nature; therefore, crying for them caused them to help their survivors and make the nature green and living. With this description, weeping and holding mourning ceremony for Siavash caused him to come back to the world of living in form of Kay Khosrow as the symbol of justice and integrity. It was at this time that his return coincided with the freshness of the nature and people used to have ceremonies and celebration for these two blessings. According to what was said, Dumuzi and Siavash have to go to the underground world of the dead and after the public mourning and magical crying that had the stimulation of the gods in the renewal of life, return to the people (Bahar, 1999: 423-430 and Bahar, 1998: 169-171).

Siavash mourning ritual with this background is still held in some parts of Iran including Kohkiloueh and Fars $^{3}$ and this shows the viability of Siavash myth among the people. Until half a century ago, tribal Lor women of Kohgiloyeh in wailing the death of their family along moaning used to sing tragic song locally called "Sio Siovash" meaning death of Siavash (Hedayat, 1955: 56).

Due to these facts, we can conclude that the root of many of mourning created after Islam has been affected by Siavash mourning rite:

"As we get closer to the Amu Darya Basin, mourning ceremonies or rites are closer to Siavash even if the mourner is Timur Gurkani" (Hasouri, 1999: 88).

However, the oldest historical document telling of Mourning for Siavash is the history of Bukhara in the third century AH. To the author of this book, in Bukhara, Siavash memory and what is called in this area as "Magi crying" is still intact: "People of Bukhara have strange minstrel songs for death of Siavash and the singers call them "Siavash rancor" and this history is three thousand years" (Narshakhi, 1992: 24).

After him Kashgari in "al-Turki words" refers to mourn over the grave of Siavash on the anniversary of his death and writes: Every year, Magi gather in Ruindej near Bukhara in the killing place of Siavash and moan and sacrifice animal and shed its blood to the tomb (Kashgari, the dictionary of words al-Turki, quoted by Hasouri, 1999: 91). Another important point in relation to Siavash mourning is "Palm handling ritual." In this ritual, mourners put a tent-like room of body of Siavash and three mourners in it on their shoulders. This room has a window that the figure of Siavash and mourners is seen through (Bloukbashi, 2001: 12-13). What is important in this ritual and myth is the relationship between the vegetation god-Siavash - with sacred palm tree that represents the hidden connections between Dumuzi to the plant nature. The existence of palm trees in this event shows the relationship of Siavash with plant nature.

\section{SiavaSh in AVESTa}

In Vedic literature, Siavash has not been mentioned, the oldest written text in which he is mentioned is Avesta. In Avesta, before speaking of Siavash, it is talked of Kay Khosrow and it is in light of him that Siavash is mentioned. In general, Siavash is named in the Avesta six times.

\footnotetext{
${ }^{3}$ Novel "Souvashan" by Simin Daneshvar shows this particular mourning ritual of Siavash being alive in this region.
} 
Siavash presence in these six times in the Avesta gives him a character that is like the character that Ferdowsi gives him Shahnameh. Although he always under his son's name and great performance revenge of Afrasiab - again the greatness of his character, promotion of intellectual, and his purity can be realized, and this is the point about him discussed in myths and epics as well.

The emergence of Siavash in Avesta include ${ }^{4} \quad$ Haoma prays "Deroasb" to give him the ability to avenge Siavash and Aghrirath:

"O Deroasb! You pure! The most powerful!

Give prosperity of chaining vicious Turan Afrasiab

and drag him in chains [and like that]

take him to Kay Khosrow on the shore of deep and wide "Chichest" lake so that he kill him in avenge for his famous young kid killed unfair and also for the avenge of brave Aghrirath (Deroasb Yašt, paragraph 18)."

Elsewhere, Yasht Kay Khosrow prays "Deroasb" to get the power to avenge Siavash from Afrasiab: "O Deroasb! You pure!

Give me the prosperity to me -the avenger son of Siavash- To kill Turani Afrasiab on the shore of deep and wide "Chichest" lake so that he kill him in avenge for his famous young kid killed unfair and also for the avenge of brave Aghrirath (Drvasb Yašt, paragraph 22)

In "Farvardin Yašt" the name of Siavash as "Kewi Siavarshan" is given among the names of the eight Koyan. (April Yašt, paragraph 132)

In "Zamyad Yašt" the name of Siavash goes among the names of eight Koyan: "The person who joined "Keyghobad" of whom when "Kay Epiveh, Kay Kavoos, Kay Arash, Kay Pashin, Kay Biarash, Kay Siavarshan (Zamyad Yašt, paragraph 71)."

Elsewhere in Zamyad Yašt, it is talked of revenging Siavash by Kay Khosrow and kill Afrasiab and Garsivaz.

"Kay Khosrow, victorious sire, the avenger son of brave Siavash- that was cowardly killed - and the avenger of brave Aghrirath chained vicious Afrasiab and his brother Garsivaz" (Zamyad Yašt, paragraph 77).

In "Blessed messenger Zoroaster," where Zarathustra speaks Good of and with blessing of Kay Goshtasb, says of him: "I hope you are beautiful and perfect like Kay Siavarshan" (Yašt last messenger Zoroaster, paragraph 3).

By studying all these, it is concluded that in this book there is no relationship between father and sonKay Kavoos and Siavash- and Siavash is an innocent person killed unfairly by Afrasiab and martyrs, so his son - Kay Khosrow - thinks of avenging him, and eventually wins.

\section{Siavsh in Pahlavi TeXts}

In the Pahlavi texts, Siavash is the son of Kavoos and father of Kay Khosrow. In Bundahisn synopsis, it reads: "Afrasiab tried another time, when Siavash was challenged, under the pretext of Soudabeh Soudabeh was the wife of Kavoos- Siavash did not go to Iranshahr. Thus, Afrasiab declined [bringing Siavash]. [Siavash] did not go to Kavoos, but he went to Turkistan, and married Afrasiab daughter. Kay Khosrow was born of her. Siavash was killed instead of him" (Bahar, 1990: 221-222).

In Bundahisn, it is talked of Gangdej: "Siavash that the dumb castle and limb, raised the flag, always battalion, was on the court, Kay put it to the ground. It has seven walls: golden, silver, iron, bronze, iron, glass, and Kasg. It has seven miles (dermis) and has fifteen gates and from gate to gate, it takes may be fifteen days to get from one gate to the other on \spring days"(Ibid: 137-138)

In Numinous Wisdom it goes that the wise asks numinous wisdom, why many people are not loyal to the covenant and continue to create $\sin$ ? The wise receives the answers to numinous received wisdom that the creation of every creature based on the wisdom is predetermined:

"Kavoos benefited from that Siavash was created from him and many others actions took place by him and Siavash has benefits such as: giving birth to Kay Khosrow and building Gangdej" (Tafazoli, 1984: 139-140).

The point of creation of Siavash in this text is the creation of Kay Khosrow and building of Gangdej that is fully discussed.

\footnotetext{
${ }^{4}$ It should be noted that in this text, the translation of the Avesta by "Jalil Doostkhah" is used.
} 
What goes of Siavash in Pahlavi texts in numinous wisdom (chapter 27, paragraph 55) and Dinkard (Book 7, Chapter 1, section 38) is that he sponsored Gangdej that according to a quotation from Bundahisn (Chapter 1, paragraph 12), Iran resurrection will come from there.

\section{Siavash in ARCHAEOLOGICAL FINDINGS}

Archaeologists take many of the rituals related to Siavash from Archaeology products. The most important ritual discovered is Siavash mourning rite.

In Iran, in Lorestan region and Marlik, some figurines are obtained that show that women are crying. Panjkand murals, pottery carvings of Marv and Osstudan from the tip of castle show mourning and weeping images of women lying down overhead or huddled (Bahar, 19998: 249-250). These designs strengthen the common belief in the sanctity of mourning for the vegetation martyring gods among Iranians.

Geographically, all the area known as Khorezm, Sogd (Panjkand, Afrasiab, Samarkand, Rakhsh, etc.) and the land called Bactria, especially Marv has the Ancient Siavashani works (Hasouri, 1999: 15)

In addition to these cases, Siavashan were held in many areas that have remained with the same name as Siavashan villages in all Iran, Siavashan Mosque in Shiraz and Siavash Siavashan Rite among tribes to West Kurdistan (Ibid, 16).

What archaeologists have gained from these findings reflect holding these rites in certain areas was time, as Framkin also noted:

"Wall Paintings remaining from the seventh and eighth centuries AD in Panjkand, by Zarafshan River about $70 \mathrm{~km}$ of Samarkand refer to a scene of mourning Siavash" (Framkin, 1993: 122-124).

In Wall Paintings of mourning of Siavash, which is an example of beautiful paintings on the wall in the region, a symbolic figure of Siavash is placed in tearful mourners Amari, and the women gathered around it and bear it. As understood from studying the above facts, it can be deduced that the origin and source of the artefacts related to Siavash are in the Khorezm that is Central Asia.

Siavash myth is one of the rarest and most important archaeological findings in Central Asia, and since the scientists have carefully investigated the items achieved, one can say that no myth has as mythical historical documents capital as Siavash and no myth has so much living proof of its size and geographical names and rituals of mourning and memorial (Hasouri, 1999: 28)

\section{CONCLUSION}

Depending on what so far told about Siavash in various fields, including myths, Avesta, Pahlavi texts, and archaeological products, it could be said that Siavash is the most immortal character that in the transition from myth to epic has passed the stages of evolution. He comes from the heaven of myth as a mighty and praiseworthy god into productive land and does his duty to bring an end to evil and darkness by creating Kay Khosrow and then again ascends to heaven in form of a completely release human.

What is offered of Siavash in Avesta and texts such as Bundahisn and numinous wisdom is just the same image that Ferdowsi presents in Shahnameh to represent different aspects of his personality and this is a point that happened to no character in the Shahnameh, because Siavash after Shahnameh continues in rituals, which have still retained their sanctity for the people.

Among these ancient traditions of Iran, "Haji Firouz", "Nowruz", "Palm handling" and "Siavash mourning rite" that still happen in some areas of Iran all remind a human that made all his efforts to remove evil and strengthening purity.

Siavash myth with growth in multiple dimensions that were mentioned in the study is one of the deepest and strangest myths created in the history of human thought. As already mentioned, this myth has various samples and similar cases in different cultures and civilizations, including Mesopotamia, Syria, Egypt, and Phoenicia and so on.

However, from examining each of these samples, it is concluded that none of these characters equivalent to Siavash mentioned above have the promotion and development both intellectually and practically in life, which is why Ferdowsi also taking into account various factors of his death on two fronts in Iran and Turan, blames the world for his innocent death: World, what do you want from the 
nurturers? Of the nurturers who have gotten mourns. Evaluating Siavash features in these areas and taking into account the unique characteristics in Shahnameh, makes it clear that that myth Siavash is the same Siavash that finds a way to Avesta. Moreover, Avesta Siavash Kay as the father of Kay Khosrow, the epic Persian king is the same Siavash that in Pahlavi texts his largest deed is building Gangdej and creating Kay Khosrow. After this, what is formed in people's mind of Siavash is the great image Ferdowsi creates that needs investigations.

\section{REFERENCES}

[1] Razi, H. (2002) Encyclopedia of Ancient Iran, Sokhan, Tehran

[2] Blukbashi, A. (1991). Palm handling (of Iran, what do I know?), The Cultural Research Bureau.

[3] Bartholome,Christian. 1961., Altiranischesworterbuch, Berlin.

[4] Bahar, M. (1998). From Myth to History, fountain.

[5] _. (1990). Bundahisn, Tous.

[6] _ (1999). Research in Iranian mythology, if.

[7] _. (1994). Essay few in Iranian culture, thought of the day.

[8] Tafazoli, A. (1984). Numinous wisdom, Toos.

[9] Hasouri, A. (1999). Siavashan, Cheshmeh.

[10] KhaleghiMotlagh, J., (1983). Shahnameh and the subject of the first man of letters, Volume 2, Issue 2

[11] Doostkhah, J., (1998). Avesta, Morvarid, 2 vols.

[12] Gay Curtis, Vesta. (1994). Iranian myths, translation Abbas rapporteur, the publishing center.

[13] Sarkarti, B. (1978). Mythological foundation of Iranian national epic, Shahnameh Studies, Studies in Shahnameh Foundation Publications, Volume 1.Safa, Z. (1999). Iranian epic poem, Paradise.

[14] Framkin, G. (1993). Archaeology in the Middle East, King Shahmirzadi true translation, printing and publishing institution Ministry of Foreign Affairs.

[15] Firdausi, A. (1999). Shahnameh (9-volume printing of Moscow), in an attempt S. Hamidian, Phoenix, Volume 3

[16] Callisthenes. (1964). Eskandar, byIrajAfshar, Translation and Publication Board.

[17] Christensen, A. (2002). Kyanian, translation ZabihullahSafa, scientific and cultural fields.

[18] Unknown author. (1939). Tavarikh succinct and Alqss, correction Mohammad TaghiBahar, East stigma.

[19] Mazdapour, K. (1990). Improper deserve, Institute for Cultural Research and Studies.

[20] Maskoub, Sh. (1988). Mourning for Siavash, Khorezm.

[21] Narshakhi, Abu Bakr Muhammad ibn Ja'far. (1992). History of Bukhara, corrected and annotated by Professor Razavi, Iranian Cultural Foundation.

[22] Sadegh, H. (1982). Sporadic efforts Hassan Ghaemian, Aut.

[23] IslamiNodoushan, M, A. (1999). Life and Death of Shah Amouzgar, J. (2001) .tarikh mythological Iran, China third, the Society national works

\section{AUTHOR's BIOGRAPHY}

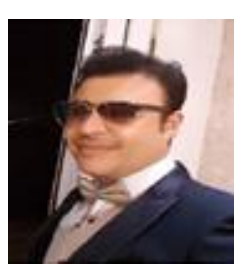

Seyed Salam Fathi, he was born in Kurdistan of Iran on February 2/1989. He lives in Tehran and grew up in Saqqez in Kurdistan province. He spent his primary \& high school in the same city after he studied history major at university of Kurdistan, then he founded history magazine with collaboration of history students. He did his M.A in ancient history of Iran at university of Tehran.

His interests are varied the ancient world history and mythology, but he mainly work on the Sasanian Empire which was the major power in the Near East, rivaling the Roman Empire. The reason he became interested in this ancient dynasty is that Near Eastern, or Middle Eastern, the history is covered somewhat strangely in the United States. He has written numerous articles for interior \&international journal and took part in many of international conferences about a history and culture of Iranian. He actively writes and works on. His other interests include writing calligraphy Gothic\& copperplate, painting, literature Iranian. He teaches calligraphy and work on other projects ancient history\& culture Iranian now. 